\title{
Assessment of the current distribution and human perceptions of the Pampas cat Leopardus colocolo in northern Peru and southern Ecuador
}

\author{
Alvaro García-Olaechea and Cindy M. Hurtado
}

\begin{abstract}
The Pampas cat Leopardus colocolo occurs in a variety of habitats from northern Ecuador to southern Argentina, yet the species has been poorly studied. There is scant information about its northern distribution or about populations in desert and dry forest. We aimed to determine the presence of the Pampas cat in the Sechura Desert and seasonally dry forest of north-western Peru and south-western Ecuador, identify threats to the species, and describe people's perceptions of it. Using 32 camera traps and compiling confirmed and unpublished records, we mapped the species' distribution and identified 12 new localities, three in the Sechura Desert and nine in the dry forest. The first records of the Pampas cat in the Ecuadorian dry forest are reported from La Ceiba Natural Reserve and Jorupe Reserve; the northernmost record in the dry forest is from Cerros de Amotape National Park, Peru. In 56 semi-structured interviews with local people we found that most of them $(76.8 \%)$ did not know the species; $61.5 \%$ of those who knew the species had a neutral perception and did not think the cat affected their personal activities. Here we update the northern distribution of the Pampas cat, describe threats to the species in arid ecosystems, and highlight the need for further studies to identify other possible threats and mitigation methods.
\end{abstract}

Keywords Arid ecosystems, conservation, feral mammals, human perceptions, Leopardus colocolo, Pampas cat, seasonally dry forest, Sechura Desert

Supplementary material for this article is available at https://doi.org/10.1017/So03060531700151X

A ssessments of the distribution of a species are important for understanding ecological preferences and are fundamentally important for conservation management (Fajardo et al., 2014). Understanding the distribution of carnivores, which usually compete with people for space and

Alvaro García-OlaecheA* (Corresponding author) and Cindy M. Hurtado† Centro de Investigación Biodiversidad Sostenible, Francisco de Zela 1556, Lima 14, Peru. E-mail a.garciao@biosperu.org

*Also at: Applied Ecology and Conservation Lab, Universidade Estadual de Santa Cruz, Ilhéus, Bahia, Brazil

$\dagger$ Also at: Department of Forest Resources Management, University of British Columbia, Vancouver, Canada

Received 4 April 2017. Revision requested 25 July 2017.

Accepted 25 September 2017. First published online 11 December 2017. food, is necessary to reduce negative human-carnivore interactions (Inskip \& Zimmermann, 2009) but our knowledge of carnivore distribution is incomplete. Specifically, the distribution of small felids, and their interactions with people in the Neotropics, has been assessed only in a few regions, (Lucherini et al., 2016), and such information is scarce for South American arid ecosystems.

The Pampas cat Leopardus colocolo is distributed from northern Ecuador to southern Argentina, in diverse habitats at o-5,704 $\mathrm{m}$ altitude (Lucherini et al., 2016). Across its distribution range it faces habitat loss, hunting, and the presence of feral dogs and livestock (Lucherini et al., 2016). The species is categorized as Near Threatened on the IUCN Red List (Lucherini et al., 2016), Data Deficient in Peru (MINAGRI, 2014) and Vulnerable in Ecuador (Tirira, 2011), but distributional and ecological research has focused on the Andean and Cerrado populations, excluding desert and dry forest populations almost entirely (Lucherini et al., 2016). Therefore, our aims were to determine the presence of the Pampas cat in the Sechura Desert and seasonally dry forest of north-western Peru and south-western Ecuador, and identify threats to the species, and how people perceive it.

During April 2015-July 2016 we surveyed eight localities of the northern Peruvian and southern Ecuadorian coastline ecosystems, in the Sechura Desert and seasonally dry forest (Table 1). These arid ecosystems are among the Global 200 priority ecoregions for global conservation (Olson \& Dinerstein, 2002; for detailed descriptions see Brack-Egg, 1986, and Linares-Palomino et al., 2010). Each locality was surveyed using 32 camera-trap stations (1o Illuminator cameras, Covert Scouting Cameras, Lewisburg, USA; 22 Trophy Cam HD cameras, Bushnell, Overland Park, USA). Stations were at least $300 \mathrm{~m}$ apart, and each station consisted of a single camera trap, set at a mean height of $30 \mathrm{~cm}$ and programmed to take three photographs per second for each detection. As felids primarily use trails and water sources in arid ecosystems (Edwards et al., 2016), cameras were positioned mostly on trails but also near water sources, and to increase the detection rate, compact disks were used as a visual attractor. The cameras were left at each locality until the Pampas cat's presence was confirmed, or for a maximum survey period of 18 nights. We calculated sampling effort as the number of camera traps multiplied by the number of active days per camera, and latency to initial detection, defined as the effort needed (camera-days) to obtain the first record of a Pampas cat in each locality. 
TABLE 1 Survey localities in the Sechura Desert and in the seasonal dry forest of north-western Peru and south-western Ecuador (Fig. 1).

\begin{tabular}{|c|c|c|c|}
\hline $\begin{array}{l}\text { Locality (by ecoregion } \\
\text { and country) }\end{array}$ & $\begin{array}{l}\text { Altitude } \\
(\mathrm{m})\end{array}$ & $\begin{array}{l}\text { Survey effort } \\
\text { (camera-days) }\end{array}$ & $\begin{array}{l}\text { Capture } \\
\text { events }\end{array}$ \\
\hline \multicolumn{4}{|l|}{ Sechura Desert (Peru) } \\
\hline Illescas Reserve Zone & 61 & 211 & 1 \\
\hline $\begin{array}{l}\text { San Pedro de Vice } \\
\text { Mangrove }\end{array}$ & 0 & 22 & 4 \\
\hline Ñapique Lake & 15 & 50 & 2 \\
\hline \multicolumn{4}{|l|}{ Dry forest (Peru) } \\
\hline El Virrey Area & 737 & 288 & 3 \\
\hline $\begin{array}{l}\text { Cerros de Amotape } \\
\text { National Park }\end{array}$ & 593 & 340 & 1 \\
\hline $\begin{array}{c}\text { Manglares de Tumbes } \\
\text { National Sanctuary }\end{array}$ & 8 & 322 & 0 \\
\hline \multicolumn{4}{|l|}{ Dry forest (Ecuador) } \\
\hline La Ceiba Natural Reserve & 538 & 468 & 12 \\
\hline $\begin{array}{l}\text { Arenillas Ecological } \\
\text { Reserve }\end{array}$ & 42 & 576 & 0 \\
\hline
\end{tabular}

Additionally, we compiled non-published but confirmed records (based on photographs) of the Pampas cat in the Sechura Desert and dry forest. We also conducted standardized semi-structured interviews with local people selected randomly from houses near field sites and door-to-door canvassing in 10 localities, to assess their knowledge about the Pampas cat and identify potential conflicts with people. This was authorized by Servicio Nacional de Áreas Naturales Protegidas (023-2015-SERNANP-DGANP), Servicio Nacional Forestal y de Fauna Silvestre (02992015-SERFOR-DFFSPFFS), and the Ecuadorian Environment Ministry (oo2-IC-FLO-DP-AEO-MAE). Each interview consisted of nine questions and included photographs of carnivores that are potentially distributed in the surveyed locality (Supplementary Material 1). We categorized interviews as No ID when the interviewee was unable to identify the Pampas cat in photographs, and ID when the interviewee successfully identified the species. Within the ID category we summarized people's perceptions as positive, negative or neutral.

During 2,277 camera-days we obtained 23 records of the Pampas cat, in six of the eight surveyed localities (Fig. 1; Plate 1). We also found one captured individual in Chapangos town, and interviews confirmed the species' presence in Yacila de Zamba Private Conservation Area. Additionally, we compiled five records from other researchers (E. Edavaly, P. Vásquez, K. Herrera, D. Tirira and M. Gómez; Fig. 1). Our updated distribution map includes 12 new records of the species: three in the Sechura Desert and nine in the dry forest. The lowest altitude at which the species was detected was o m, in San Pedro de Vice Mangrove, and the highest altitude was near Kuelap Arqueological Site, at 2,210 m. San Pedro de Vice Mangrove was the

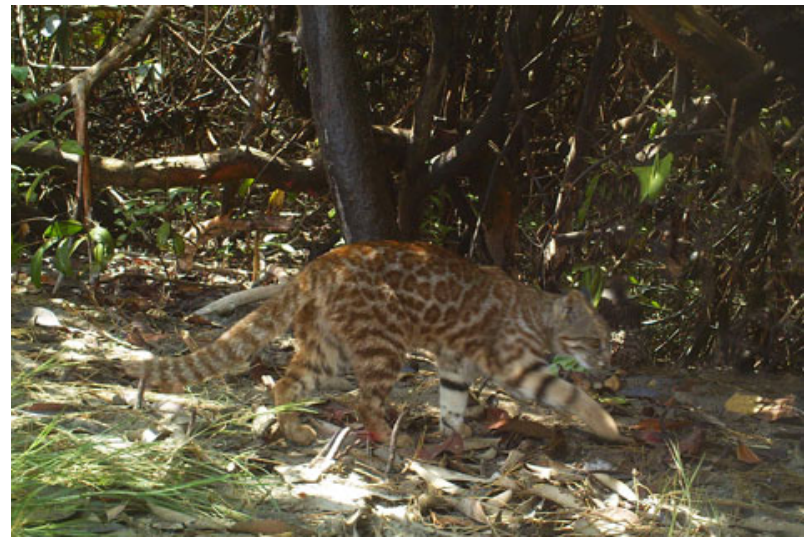

Plate 1 Pampas cat Leopardus colocolo in San Pedro de Vice Mangrove, Peru.

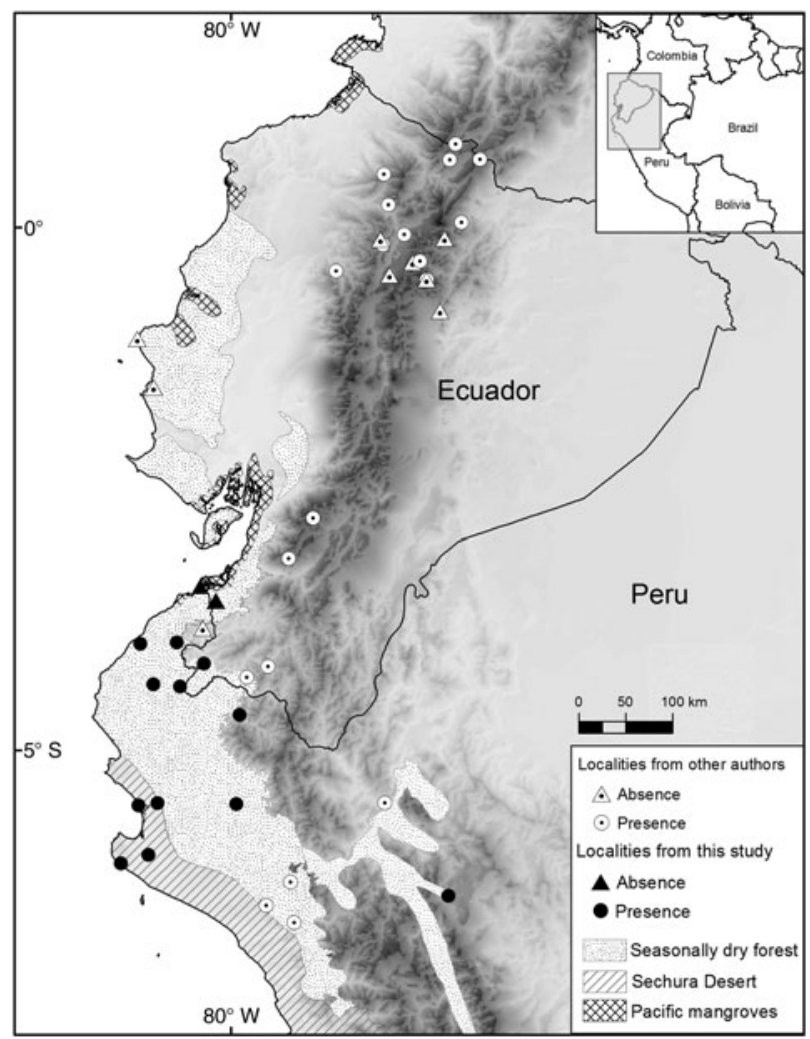

FIg. 1 Records of the Pampas cat Leopardus colocolo in the Sechura Desert, Peru, and seasonally dry forest of Peru and Ecuador.

location with the lowest latency to initial detection (11 camera-days), followed by Napique Lake ( 25 camera-days); Cerros de Amotape National Park had the highest latency to initial detection (193 camera-days; Fig. 2).

We identified several threats to the Pampas cat. In the Sechura Desert the cat lives among feral mammals (dogs, cats, donkeys, goats and pigs), which can be direct competitors, and may serve as vectors for disease transmission (Doherty et al., 2016). Habitat loss in San Pedro de Vice 


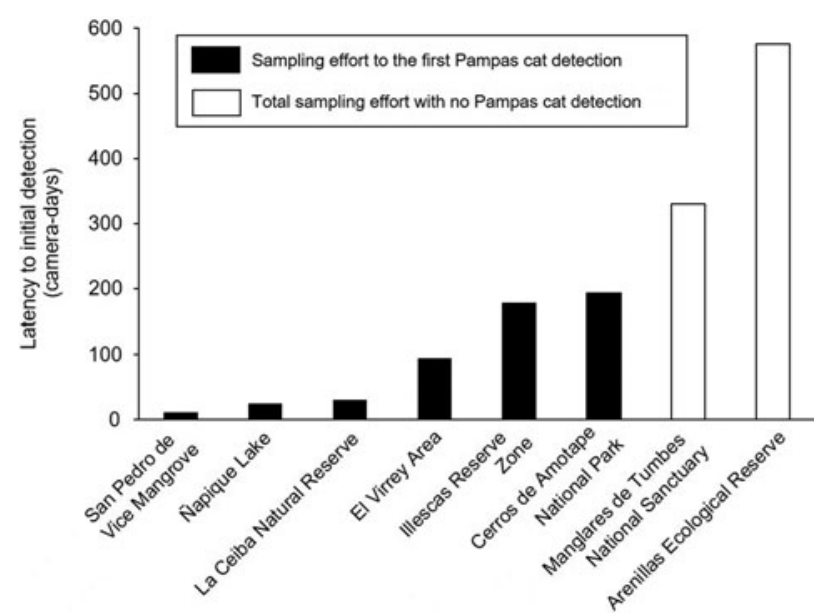

FIG. 2 Latency to initial detection in the localities surveyed for the Pampas cat in the Sechura Desert, Peru, and seasonally dry forest of Peru and Ecuador (Fig. 1).

Mangrove is driven by wildfires set deliberately and repeatedly by local people to facilitate hunting of feral pigs, and habitat degradation in Cerros de Amotape National Park and La Ceiba Natural Reserve is caused by free-ranging livestock (cattle and goats). The only reported capture of a Pampas cat involved an opportunistic event in which local people tried to obtain income from selling a juvenile as a pet, in Chapangos town.

We interviewed 56 people (44 in Peru and 12 in Ecuador) from 10 settlements. The interviewees were farmers, fishers, park guards, housewives and school children. Among these, 23.2\% (13) were familiar with the Pampas cat, of which $23.1 \%$ (3) had a positive perception of the species, $61.5 \%$ (8) were neutral to its presence, and $15.4 \%$ (2) had a negative perception. Park guards had a positive perception of the species, whereas fishers had a neutral perception. Only farmers perceived the Pampas cat negatively, on the basis that it preyed upon their young goats and poultry.

Most previous records of this species in Peru and Ecuador were concentrated in the Andes (Lucherini et al., 2016), despite assessments of mammal diversity having been carried out in the dry forests of both countries (Espinosa et al., 2016). We found evidence of the species at La Ceiba Natural Reserve (this research) and Jorupe Reserve (Tirira, 2017), which are the first known localities of the Pampas cat in the Ecuadorian dry forest. Our findings extend the known distribution of the species $\mathrm{c} .18 \mathrm{o} \mathrm{km}$ north to Cerros Amotape National Park, which may be the northern limit of its distribution in the dry forest ecosystem.

The differences in latency to initial detection in the Sechura Desert localities may be attributed to lower cat density because of prey availability and weather constraints in the Illescas Reserve Zone, compared to both wetlands in the same ecoregion. The higher latency to initial detection in Cerros
Amotape National Park compared to the Sechura Desert wetland localities may be explained by the presence of three other small cat species: Leopardus pardalis, Leopardus wiedii and Puma yagouaroundi (Hurtado \& Pacheco, 2015). High interspecific competition among these species could constrain the Pampas cat, which does not usually occur in forested ecosystems (Lucherini et al., 2016), and may also explain the lack of records of the species in the Arenillas Ecological Reserve, where L. pardalis and P. yagouaroundi coexist (Espinosa et al., 2016). We found no evidence of the Pampas cat in surveys of various dry forest patches near the Manglares de Tumbes National Sanctuary, possibly as a result of long-term flooding of this forest, which makes it unsuitable for this species (Lucherini et al., 2016).

Most local people are not familiar with the Pampas cat, and conflict with the species appears to be rare in the surveyed localities. The interviewees who had a negative perception of the Pampas cat mentioned that it preys on poultry and young goats, although there is no evidence of this. Predation of young goats is usually attributed to the puma Puma concolor (Inskip \& Zimmermann, 2009), whereas poultry is a preferred prey of the Sechuran fox Lycalopex sechurae (Cossíos Meza, 2004). Thus, we recommend that future environmental workshops and talks be customized and targeted towards people unfamiliar with the species and towards farmers who may erroneously believe the Pampas cat is preying on their animals.

Our findings show that Pampas cat populations are widely distributed in arid ecosystems, tolerating some degree of disturbance and the presence of other small felid species at low densities. This information may be used as a baseline for future research. Additionally, given people's neutral perception of the Pampas cat, there is potential for educational programmes to increase awareness of the species and highlight the importance of protecting the Sechura Desert and dry forest.

\section{Acknowledgements}

Funding was provided by the Mohamed bin Zayed Species Conservation Fund, Small Wild Cat Conservation Foundation, and San Diego Zoo Global. We thank Servicio Nacional de Áreas Naturales Protegidas (0232015-SERNANP-DGANP), Servicio Nacional Forestal y de Fauna Silvestre (0299-2015-SERFOR-DFFSPFFS), Jaime Salas, and the Ecuadorian Environment Ministry (OO2-IC-FLO-DP-AEO-MAE) for research authorizations. We are grateful for the support of Jim Sanderson and volunteers: Jorge Novoa, Diego García, Elio Nuñez, Luiggi Quevedo, Ivan Wong, Kárlom Herrera, Zoila Vega, J.L. Troncos, J.P. Castro, Darwin Martínez, Cristian Barros, Pablo Martínez, Carlos Pingo, Yufani Olaya, Edgar Espinoza, Omar Aguilar and Felipe Sánchez. We also 
thank Diego Tirira, Pedro Vásquez, Elberth Edevaly, Marlo Gómez and Russ Van Horn for helping improve this article.

\section{Author contributions}

AGO and CMH designed the study and collected and analyzed the data. AGO wrote the article and $\mathrm{CMH}$ provided relevant comments and revisions.

\section{References}

BRACK-EgG, A. (1986) Las ecorregiones del Perú. Boletín de Lima, 44, 57-70.

Cossios Meza, E.D. (2004) Relaciones entre el zorro de Sechura, Pseudalopex sechurae, y el hombre en el Perú. Ecología Aplicada, 3 , 134-138.

Doherty, T.S., Glen, A.S., Nimmo, D.G., Ritchie, E.G. \& Dickman, C.R. (2016) Invasive predators and global biodiversity loss. Proceedings of the National Academy of Sciences of the United States of America, 113, 11261-11265.

Edwards, S., Gange, A.C. \& Wiesel, I. (2016) An oasis in the desert: the potential of water sources as camera trap sites in arid environments for surveying a carnivore guild. Journal of Arid Environments, 124, 304-309.

Espinosa, C.I., Jara - Guerrero, A., Cisceros, R., Sotomayor, J.D. \& Escribano-Ávila, G. (2016) Reserva Ecológica Arenillas; ¿un refugio de diversidad biológica o una isla de extinción? Ecosistemas, 25, 5-12.

Fajardo, J., Lessmann, J., Bonaccorso, E., Devenish, C. \& MuÑoZ, J. (2014) Combined use of systematic conservation planning, species distribution modelling, and connectivity analysis reveals severe conservation gaps in a megadiverse country (Peru). PLOS ONE, 9(12), e114367.
Hurtado, C.M. \& Pacheco, V. (2015) New mammalian records in the Parque Nacional Cerros de Amotape, northwestern Peru. Revista Peruana de Biología, 22, 77-86.

Inskip, C. \& Zimmermann, A. (2009) Human-felid conflict: a review of patterns and priorities worldwide. Oryx, 43, 18-34.

Linares-Palomino, R., Kvist, L.P., Aguirre-Mendoza, Z. \& Gonzales-Inca, C. (2010) Diversity and endemism of woody plant species in the Equatorial Pacific seasonally dry forests. Biodiversity and Conservation, 19, 169-185.

Lucherini, M., Eizirik, E., de Oliveira, T., Pereira, J. \& W ILliams, R.S.R. (2016) Leopardus colocolo. In The IUCN Red List of Threatened Species 2016: e. T15309A97204446. Http://dx.doi.org/ 10.2305/IUCN.UK.2016-1.RLTS.T15309A97204446.en [accessed 4 February 2017].

MINAGRI (2014) Decreto Supremo Nº04-2014-AG. Ministerio de Agricultura, Lima, Peru.

Olson, D.M. \& Dinerstein, E. (2002) The Global 200: priority ecoregions for global conservation. Annals of the Missouri Botanical Garden, 89, 199-224.

Tirira, D.G. (ed.) (2011). Libro rojo de los mamíferos del Ecuador. Serie Libros Rojos del Ecuador. Vol. 1. Publicación especial sobre los mamíferos del Ecuador. Simbioe/Ecociencia/Ministerio del Ambiente/IUCN, Quito, Ecuador.

Tirira, D.G. (2017) Red Noctilio. Base de datos no publicada sobre los mamíferos del Ecuador. Unpublished report. Grupo Murciélago Blanco, Quito, Ecuador.

\section{Biographical sketches}

Alvaro García-Olaechea and Cindy Hurtado are interested in the ecology and conservation of medium- to large-sized mammals. Both work mainly on the mammals of Peruvian tropical forests. Alvaro's experience includes bird monitoring, and Cindy has conducted research on reintroduced peccaries in Argentina. 